\title{
Aplikasi Latihan Soal Bahasa Indonesia Berbasis E-Learning
}

\author{
Irma Eka Ariyani ${ }^{1 *}$, Nur Lailatul Hibatullah T. ${ }^{2}$, Yustika Indrijati ${ }^{3}$, Miftakhul Huda ${ }^{4}$ \\ 1,2,3,4 Pendidikan Bahasa dan Sastra Indonesia, Universitas Muhammadiyah Surakarta, Sukoharjo, Indonesia \\ *Corresponding author: irmaekaariani@gmail.com
}

\section{Abstrak}

\begin{abstract}
Masih banyak guru yang kurang paham atau kurang tepat dalam menerpakan strategi pembelajaran yang digunakan untuk mengajar, sehingga kesuksesan dalam proses pembelajaran kurang efisien atau kurang maksimal. Penelitian ini bertujuan untuk mengembangkan aplikasi latihan soal bahasa Indonesia berbasis e-learning. Metode penelitian ini adalah Research and Development (R\&D) salah satu penelitian yang mengembangkan suatu produk atau menyempurnakan produk. Subjek penelitian ini adalah siswa. Teknik pengumpulan data yaitu observasi dan studi dokumen, yang kemudian dianalisis menggunakan teknik reduksi data dan triangulasi. Hasil penelitian meliputi proses pengembangan aplikasi yang dilengkapi berbagai fitur untuk menyajikan latihan soal. Berdasarkan hasil pengembangan aplikasi ini dapat digunakan pada evaluasi pembelajaran. implikasi penelitian ini dalalm menenerapkan pembelajaran E-learning menggunakan aplikasi latihan soal dapat digunakan dimanapun dan kapanpun. Guru dapat membuat soal dengan mudah jika menggunakan aplikasi ini. Guru dapat mengevaluasi dan mengukur ketercapaian peserta didik terhadap materi yang telah dipelajari, tanpa menggunakan atau membeli kertas, dengan begitu akan menghemat waktu serta biaya.
\end{abstract}

Kata kunci: Aplikasi Latihan Soal, E-Learning

\section{Abstract}

There are still many teachers who do not understand or are less precise in applying the learning strategies used to teach, so that success in the learning process is less efficient or less than optimal. This study aims to develop an e-learning-based Indonesian language practice application. This research method is Research and Development $(R \& D)$ one of the studies that develops a product or improves a product. The subjects of this research are students. Data collection techniques are observation and document study, which are then analyzed using data reduction and triangulation techniques. The results of the study include the application development process which is equipped with various features to present practice questions. Based on the results of the development of this application can be used in the evaluation of learning. The implications of this research in implementing E-learning learning using practice questions applications can be used anywhere and anytime. Teachers can make questions easily when using this application. Teachers can evaluate and measure students' achievement of the material that has been studied, without using or buying paper, thus saving time and costs.

Keywords: Application Practice Questions, E-Learning

$\begin{array}{ll}\text { History: } & \text { Publisher: Undiksha Press } \\ \text { Received : 26 April 2020 } & \text { Licensed: This work is licensed under } \\ \text { Revised }: 25 \text { Mei } 2020 & \text { a Creative Commons Attribution 4.0 License } \\ \text { Accepted : 18 April 2021 } & \text { Patis } 2021\end{array}$

\section{Pendahuluan}

Perkembangan ilmu dan teknologi pada zaman ini telah mencapai perkembangan yang sangat pesat (Astuti et al., 2017; Kuswanto et al., 2017). Perlunya pengembangan dan mengelola teknologi dalam dunia pendidikan. Teknologi komputer telah merubah dunia pendidikan menjadi lebih luas dan tidak terbatas dalam pembelajaran (Adhi, 2018; Huda, 2018). E-learning salah satu inovasi pembelajaran yang dikembangkan oleh para ahli teknologi informatika sebagai perkembangan pembelajaran maupun tenaga kependidikan (Cucus \& Aprilinda, 2016; Shetu et al., 2021). Pembelajaran suatu peroses interaksi antara pendidik dengan peserta didik menggunakan perantara sumber belajar di dalam kegiatan pembelajaran yang terjadi proses perolehan ilmu pengetahuan, pembentukan karakter, penguasaan kemahiran, dan kepercayan peserta didik (Setiawan, 2020).

Kenyataannya dilapangan, mayoritas sekolah masih banyak guru yang kurang paham atau kurang tepat dalam menerpakan strategi pembelajaran yang digunakan untuk mengajar, sehingga kesuksesan dalam proses pembelajaran kurang efisien atau kurang maksimal dalam menjalankannya. Kualitas pembelajaran sangat bergantung pada motivasi peserta didik dan 
kreatifitas pendidik (Suprihatin, 2015). Pendidik di Indonesia masih banyak yang memberikan evaluasi secara manual, seperti membuat soal melalui Microsoft Word yang kemudian dicetak (Pakpahan \& Fitriani, 2020). Sehingga peserta didik mengerjakan soal tersebut menggunakan media kertas sebagai lembar jawaban. Hanya membuat soal saja pendidik harus bekerja dua kali, belum lagi kertas soal dan jawaban harus dibagikan menyeluruh kepada semua peserta didik. Tidak hanya itu pendidik atau pihak sekolah harus mengeluarkan biaya untuk mencetak soal tersebut. Kemudian jika soal telah dikerjakan oleh peserta didik, pendidik harus mengumpulkannya kembali lalu mengoreksi hasil jawaban siswa. Tentu mengoreksi jawaban secara manual dengan membaca hasil jawaban siswa adalah kegiatan yang membutuhkan waktu lama. Sehingga peserta didik tidak dapat mengetahui hasil ketercapaian materi yang telah diperoleh. Memanfaatkan IT pada proses pembelajaran salah satu terobosan atau inovasi agar meningkatkan motivasi dan pemahaman peserta didik, serta menciptakan suasana yang nyaman dan menyenangkan (Aprianto, 2021).

Pembelajaran berbasis IT difokuskan pada e-learning sebagai inovasi metode pembelajaran, akan terlihat dengan jelas bagaimana e-learning kaitannya dengan aplikasi dan pembelajaran (Cucus \& Aprilinda, 2016; Pudyastuti \& Budiningsih, 2021). e-learning yakni pembelajaran jarak jauh yang menggunakan rangkaian elektronik yang diprogram melalui komputer dilakukan melalui media internet untuk menyampaikan sebuah isi pembelajaran, interaksi pendidik dengan peserta didik atau bimbingaan yang memperoleh bahan ajar sesuai kebutuhan (Cucus \& Aprilinda, 2016; Ichsan et al., 2020; Sofralda, Suci \& Atika Latifa, 2019). Strategi pembelajaran yang baik, dapat ditunjang dengan fasilitas yang memadai agar siswa lebih mudah mencapai tujuan belajar (Wardani, 2021). Salah satu strategi yang dapat digunakan yaitu media pembelajaran berbasis e-learning yang dibuat oleh kreativitas pendidik dapat menarik minat peserta didik dalam proses pembelajaran.

Media pembelajaran adalah salah satu media sumber belajar yang bertujuan untuk keperluan pembelajaran yang terdiri dari dua unsur yaitu unsur hardware dan software (Aka, 2017; Hanik, 2020). Media pembelajaran dapat diprogram dengan menggunakan perkembangan teknologi membuat pembelajaran lebih menarik dan memberikan dampak positif bagi dunia pendidikan berupa motivasi belajar dan hasil belajar (Sutrisno \& Siswanto, 2016). Media berbasis IT yaitu alat interaktif yang dapat digunakan oleh siapa saja, dimana saja, kapan dan disiarkan kepada siapapun melalui internet (Damayanti \& Dewi, 2021). Jika menggunakan media elektronik ini akan sangat mempengaruhi efektivitas pembelajaran sebagai media informasi dan hiburan dalam dunia pendidikan. Salah satu media elektronik yang dapat digunakan adalah aplikasi mobile learning (Wan Normeza Wan Zakaria et al., 2019). Aplikasi dalam bentuk ponsel android merupakan solusi yang bisa di gunakan pendidik untuk proses belajar mengajar yang proses penggunaanya tidak membutuhkan banyak waktu, jadi aplikasi berbasis soal ini sangat efesien jika digunakan dalam pembelajaran(Safitri \& Nurkamilah, 2020). Aplikasi soal merupakan kumpulan pertanyaan yang memudahkan pendidik untuk menyusun soal sebagai alat evaluasi agar dapat mengukur ketercapaian materi peserta didik (Sayyidati \& Effendy, 2018). Aplikasi latihan soal digunakan untuk mengevaluasi materi yang telah disampaikan oleh pendidik secara mudah dan cepat, agar mengetahui hasil pengetahuan peserta didik dalam mendalami materi (Yasa et al., 2020).

Temuan penelitian sebelunya menyatakan siswa dapat menggunakan aplikasi seluler untuk menunjukkan berbagai tugas dalam pembelajaran formal dan informal (Kurniawan et al., 2020). Siwa dapat menggunakan beberapa aplikasi pendidikan yang sudah ada untuk menyelesaikan kegiatan belajar (Anugrahana, 2020). Dengan menggunakan aplikasi seluler, tugas-tugas ini dapat dilakukan di mana saja dan kapan saja. Kemudian aplikasi seluler tersebut dapat digunakan di berbagai mata pelajaran di dalam dan di luar kelas. Aplikasi seluler ini mampu berjalan pada perangkat seluler pelajar untuk menyampaikan pembelajaran 
(Khaddage, 2016). Oleh sebab itu peneliti mengembangkan aplikasi latihan soal sebagai media selelur yang dapat digunakan dalam pembelajaran mobile, memberikan pengalaman peserta didik yang berbeda dan menyenangkan (Huda, 2018; Sjukur, 2012). Memanfaatkan teknologi dengan fitur-fitur baru dalam upaya untuk menghubungakan pelajar agar menggunakan teknologi (Shetu et al., 2021). Pendidik dapat melakukan ujian kapanpun dan dimanapun jika menggunakan aplikasi ini. Penelitian mengembangkan inovasi pada aplikasi berbasis android sebagai alat pengukur tingkat ketercapaian pengetahuan peserta didik. Sehingga dapat digunakan secara efektif dan efisien serta menghemat biaya dan waktu. Aplikasi latihan soal ini karena model teknologi sangat berguna sekali dalam mengaitkan pembelajaran yang pendidik akan gunakan untuk mengajar. Tujuan penelitian ini yaitu mengembangkan aplikasi latihan soal Bahasa indonesia berbasis e-learning. Adanya aplikasi soal berbasis online diharapkan dapat mengatasi masalah persoalan seperti tidak perlu bertatap muka dan dapat dilakukan dengan jarak jauh yang menghemat biaya dan waktu.

\section{Metode}

Penelitian ini menggunakan metode Pengembangan atau Research and Development (R\&D).. Produk dapat berbentuk hardware dan software, namun dalam penelitian ini produk yang dihasilkan bersifat sofware yang akan digunakan dalam pembelajaran. Penelitian pengembangan (R\&D) dalam dunia pendidikan sebagai proses yang digunakan untuk mengembangkan serta memvalidasi produk-produk pendidikan. Langkah dari proses ini berdasarkan hasil temuan penelitian yang berkaitan dengan produk yang kemudian akan dikembangkan. Produk yang dihasilkan berupa aplikasi latihan soal suatu media pembelajaran guna membantu pendidik dalam proses belajar mengajar khususnya untuk mengevaluasi peserta didik. Subjek dalam penelitian ini adalah peserta didik yang menggunakan aplikasi latihan soal. Pengumpulan data dalam penelitian ini adalah observasi dan studi pustaka. Observasi dilakukan melalui pengamatan terhadap pendidik dan peserta didik. Sedangkan studi dokumen dilakukan dengan mempelajari dan mengkaji semua dokumen yang berkaitan dengan aplikasi latihan soal, e-learning, dan mobile learning. Data adalah segala fakta berupa sekumpulan informasi yang disediakan dan dikumpulkan oleh peneliti dapat diolah atau dianalisis untuk memberikan jawaban atas rumusan masalah yang dikaji. Adapun data yang berwujud aplikasi laihan soal. Sumber data dalam penelitian ini menggunakan data sekunder. Data tersebut berupa manusia, peristiwa dan tingkah laku, dokumen atau arsip seperti jurnal atau buku. Teknik analisis data yang terkumpul akan mendapatkan kesimpulan yang valid. Teknis data yang digunakan yaitu Reduksi Data prosesnya dilakukan selama proses penulisan berjalan. Analisis data triangulasi untuk menyococokan atau membandingkan informasi dan data bertolak pada teori yang ada pada kepustakaan. Kemudian data dikumpulkan dan dipilih secara selektif sesuai dengan objek penelitian. Reliabilitas pada penelitian ini suatu pertimbangan saat melakukan penilaian keilmiahan pada temuan penelitian, sampai dimana temuan penelitian menunjukan konsistensi hasil temuan saat dilakukan oleh peneliti berbeda beserta waktu penelitian berbeda tetapi menghasilkan data yang serupa. Sedangkan validitas berkaitan dengan akurasi penelitian yang hasilnya dapat digunakan oleh populasi dimana sampel penelitian diperoleh.

\section{Hasil dan Pembahasan}

Tahap yang dilakukan untuk sebuah tujuan guna menentukan pembuatan aplikasi, penggunaan sistem, untuk mencari materi pembelajaran, menentukan konsep-konsep yang akan dibuat pada aplikasi dan perangkat yang sudah disesuaikan untuk digunakan didalam pembuatan fitur aplikasi latihan soal berbasis e-learning. Pembuatan aplikasi latihan soal berbasis e-learning, bertujuan untuk membantu pendidik dan peserta didik mengevaluasi 
pencapaian materi dengan menyajikan pembelajaran yang interaktif. Target yang ingin dicapai yakni para pengguna aplikasi-aplikasi khususnya Pendidik dan Peserta Didik. Pada identifikasi pengguna dapat memenuhi kebutuhan agar mudah mengevaluasi atau mengukur mencapaian peserta didik dengan mudah tanpa terhalang ruang dan waktu. Analisis kebutuhan ini berdasarkan pengamatan mengenai kebutuhan yang sudah dianalisis yakni mengenai fungsi dari aplikasi yang ingin dibuat dan diharapkan pada aplikasi latihan soal dapat membantu Pendidik dan Peserta Didik.

Material Collecting. Pada tahap ini bahan untuk penunjang aplikasi latihan soal gambar dan audio yang digunakan untuk dikumpulkan terlebih dahulu. Bahan yang tersedia tidak hanya bahan yang sudah siap namun juga bahan-bahan yang dibuat atau dimodifikasi yang tepat dengan kebutuhan. Konten-konten bergambar dari internet serta melewati proses memodifikasi menggunakan perangkat lunak (pengolah gambar), selain itu untuk audio dan cara mengunduh melalui internet serta merekam suara materi. Selanjutnya tahap Assembly. Untuk tahap ini lebih dilakukan implementasi mengenai hasil untuk perancangan, tahap ini meliputi tahap-tahap pembuatan aplikasi yakni pembuatan aplikasi yang berdasarkan struktur menu atau form yang sudah ada di dalam hasil penelitian. Teknologi informasi berkembang sangat cepat dalam era globalisasi. Berkembangnya internet menghasilkan informasi yang mudah untuk diakses dimanapun, kapanpun menggunakan telepon seluler, laptop, tablet, komputer, televisi. Inovasi dalam dunia pendidikan tidak akan ada henti-hentinya untuk memenuhi kebutuhan manusia dalam meningkatkan kualitas belajar. E-learning menjadi alternatif dalam metode pembelajaran, secara tidak langsung menganjurkan untuk menciptakan inovasi dalam kegiatan belajar mengajar agar lebih menyenangkan dan menarik peserta didik untuk mengikuti pembelajaran. Peserta didik akan lebih mudah menyerap pengetahuan yang disampaikan oleh pendidik apabila metode yang digunakan berbeda dari sebelumnya. Dalam implementasi program akan mendeskripsikan sistem dari kegunaan dari form dan fitur. Form Awal merupakan form pertama atau permulaan dari aplikasi ini.

Form ini berisi daftar apabila belum mempunyai akun maka pendidik membuat akun terlebih dahulu menggunakan email yang terdaftar seperti Gmail/Yahoo. Kemudian memasukan nama untuk akun. Setelah itu membuat kata sandi untuk akun baru. Mengisi sekolah atau universitas tempat guru mengajar. Form Masuk Aplikasi, pada form ini apabila pendidik sudah mempunyai akun, pendidik dapat langsung masuk menggunakan email dan kata sandi. Bagi peserta didik dapat langsung mengakses dengan memasukan kode akses latihan soal. Peserta didik dapat memasukkan kode untuk memulai latihan soal yang sudah dibuat oleh pendidik. Pertama peserta didik memasukkan kode latihan soal berupa nomer yang diberikan pendidik. Kemudian klik lanjut untuk melanjutkan tahap selanjutnya. Form Nama Peserta Didik dan Berapa Banyak Peserta Didik yang Bergabung. Pada tahap ini peserta didik mengisi nama untuk mengidentifikasi pengguna aplikasi. Lalu peserta didik mengklik lanjut untuk ketahap selanjutnya. Pada smartphone pendidik akan muncul nama dan jumlah peserta didik yang bergabung, selanjutnya pendidik akan memulai latihan soal dengan mengklik tombol start jika semua nama peserta didik sudah lengkap.

Fitur membuat soal pilihan ganda. Pada form ini terdapat 3 menu untuk membuat soal yakni; a) Menu soal pilihan ganda, b) Menu benar atau salah , dan c) Naik Level. Pendidik dapat memilih salah satu menu yang sesuai dengan materi ajar. Pada form ini guru dapat membuat soal memberikan gambar atau vidio yang berdusari, 10-20 detik. Pendidik dapat menambahkan beberapa soal, dapat melihat skor dan ranking peserta didik. Pada fitur pilihan ganda, pendidik dapat membuat dan menambahkan beberapa soal. Pendidik dapat memasukkan jawaban A,B,C,D kemudian memilih jawaban yang benar dengan cara double klik pada jawaban yang benar. Tanda ceklis menunjukkan jawaban benar yang telah dipilih oleh pendidik. Peserta didik harus memilih salah satu diantara jawaban tersebut. 
Fitur Benar atau Salah dan Naik Level. Pada fitur Benar atau Salah ini terdapat soal yang dapat ditambahkan gambar atau video. Soal tersebut harus berupa pernyataan yang membuat peserta didik harus memilih salah satu diantara jawaban apakah pernyataan tersebut benar atau salah. Kemudian pada fitur Naik Level terdapat soal yang jawabannya dapat berisi kalimat yang dibuat oleh pendidik dengan urutan yang salah, kemudian peserta didik harus mengurutkan jawaban dengan benar agar bisa lanjut ke tahap soal yang lebih sulit. Contoh soal dalam materi bahasa Indonesia teks prosedur dapat menggunakan fitur ini. Tahap-tahap ketika membuat sesuatu dalam teks prosedur dapat disusun secara tidak urut kemudian siswa harus menjawab berdasarkan urutan yang benar. Jika peserta didik dapat menjawab dengan benar maka akan lanjut ke soal berikutnya dengan tingkatan yang lebih sulit.

Form Analisis Jawaban Peserta Didik. Pada form ini setelah mengisi satu soal, dalam perangkat pendidik dan peserta didik akan muncul jawaban benar dan salah. Tanda silang untuk menunjukan jawaban yang salah. Sedangkan tanda centang menunjukan jawaban yang benar. Jika peserta didik memilih jawaban yang salah maka jawaban yang benar juga akan terlihat. Hal ini berfungsi agar peserta didik dapat langsung merefleksi dan mengingat jawabannya jika salah yang kemudian hari tidak diulangi kembali. Pendidik dan peserta didik dapat langsung melihat skor yang yang dicapai. Pada Fitur Pilihan Ganda akan menunjukkan berapa banyak peserta didik yang menjawab A/B/C/D. Kemudian terdapat tanda ceklis yang menunjukan jawaban benar, sedangkan tanda silang menunjukan jawaban yang salah. Sedangkan pada Fitur Benar atau Salah menunjukkan berapa banyak peserta didik yang menjawab A/B yang terdapat dilayar smartphone pendidik/peserta didik dalam aplikasi tersebut. Pada tampilan jawaban Fitur Naik Level ini hanya ditunjukan urutan jawaban mulai dari jawaban yang paling benar. Kemudian peserta didik dapat melihat skor yang telah dicapai setelah menjawab soal. Pada perangkat pendidik atau peserta didik akan muncul total skor dan ranking yang telah dicapai oleh peserta didik. Pendidik, dapat menyimpan hasil skor yang telah dicapai peserta didik.

Tabel 1. Konsep Aplikasi

\begin{tabular}{ll}
\hline Judul & Aplikasi Latihan Soal \\
\hline Responden & Pendidik dan Peserta Didik \\
\hline Fitur & Pembuatan soal Quiz, True or False, Level Up, Skor dan Ranking \\
\hline Gambar & Gambar dengan format .png \\
\hline Suara & Instrumen mp3 \\
\hline Interaktivitas & $\begin{array}{l}\text { Tombol lanjut dan kembali dari satu scane ke scane lain, masukan kode } \\
\text { (enter your code), simpan. }\end{array}$ \\
\hline
\end{tabular}

Menu dalam aplikasi latihan soal seperti; kuis, salah atau benar, merupakan salah satu tipe dalam metode pembelajaran aktif learning yang berfungsi untuk menghidupkan susana proses belajar mengajar, membuat siswa aktif dan antusias dalam belajar, menjawab pertanyaan, dan meningkatkan tanggung jawab siswa terhadap materi ajar melalui cara yang lebih menyenangkan dan tidakakan membosankan. Dengan memberikan pertanyaan atau kuis yang disajikan menggunakan teknologi maka peserta didik secara tidak langsung akan ikut aktif bekerja keras untuk menjawab pertanyaan. Aplikasi multimedia pembelajaran interaktif berbasis mobile untuk menunjang sebuah proses belajar mengajar (Nurhayati \& Muharamsah, 2020). Aplikasi ini mempermudah pendidik menyampaikan materi menggunakan mobile, pendidik tidak harus menjelaskan materi budaya indonesia secara mendetail seperti model pembelajaran konvensional. Pendidik hanya sebagai fasilitator, materi yang disajikan dalam aplikasi ini yakni; 1) Rumah Adat, 2) Pakaian Adat, 3) Alat Musik Tradisional, dengan begitu dengan mudah menerima materi serta dapat belajar secara 
mandiri dimanapun dan kapanpun. Hanya menampilkan nilai secara individu. Aplikasi ini sangat efektif dan dengan mudah diakses serta dapat digunakan oleh semua jenjang pendidikan, kemudian aplikasi latihan soal juga dapat digunakan oleh semua mata pelajaran. Aplikasi ini juga dapat menampilkan ranking secara keseluruhan peserta didik yang telah mengikuti latihan soal.

Temuan penelitian sebelumnya terkait aplikasi soal menyatakan aplikasi ini dapat mempermudah pembelajaran untuk siswa dan pendidik tidak harus menjelaskan isi dari materi . namun aplikasi Quiz hanya dapat di gunakan di laptop maupun komputer yang mendukung aplikasi, serta dapat dijalankan meski tanpa harus terkoneksi dengan jaringan internet (bersifat offline) (Yana et al., 2019). Temuan lain menyatakan aplikasi dengan menerapkan audio dan gambar - gambar binatang yang mudah untuk dikenali dan dapatpula digunakan sebagai pemecahan masalah dari kurangnya keinginan untuk anak belajar (Adhi, 2018; Fazriyah et al., 2020). Serta menerapkan pemberian poin dari soal yang dijawab oleh anak-anak sehingga anak lebih tertantang. Aplikasi yang dikembangkan sebagai alat pengukur ketercapaian peserta didik terdapat materi pelajaran. Selain itu lebih tersrtuktur dan lebih mudah di gunakan dan sangat efektif untuk di bawa kemana- mana tanpa harus membuka laptop maupun komputer, serta aplikasi ini dapat pula mencakup semua mata pelajaran. Aplikasi ini menghasilkan produk media pembelajaran yang berisi halaman evaluasi soal pilihan ganda yang berfungsi sebagai alat pengukur kemampuan peserta didik dalam media pembelajaran. Fitur evaluasi tidak hanya pilihan ganda tetapi juga fitur benar atau salah dan fitur naik level. Sehingga peserta didik tidak merasa bosan ketika mengerjakan soal. Implikasi penelitian ini dapat dimanfaatkan oleh guru untuk sarana pembelajaran sebagai terobosan pembelajaran jarak jauh dan sebagai alat pengukur ketercapaian materi peserta didik. . Sistem pada aplikasi ini masih dibutuhkan pengembangan yang lebih baik dalam menambahkan fitur. Untuk mengetahui kelayakan aplikasi latihan soal ini di perlukan uji coba oleh para peneliti selanjutnya, serta untuk mengetahui keefektifitas perlu di lakukan eksperimen untuk melibatkan penggunaan secara keseluruhannya.

\section{Simpulan}

Berdasarkan pembahasaan dari hasil penelitian yang diperoleh, maka dapat ditarik kesimpulan bahwa dengan menerapkan pembelajaran E-Learning menggunakan Aplikasi Latihan Soal dapat digunakan dimanapun dan kapanpun. Dengan menggunakan aplikasi latihan soal untuk mengevaluasi pendidik tidak perlu menggunakan atau membeli kertas, pendidik dapat menghemat waktu dan biaya. Aplikasi ini dikembangkan berfungsi untuk mempermudah Pendidik dan Peserta Didik dalam mengukur ketercapaian materi ajar. Aplikasi Latihan Soal Bahasa Indonesia tidak hanya berfokus pada satu mata pelajaran dan tidak berfokus pada satu jenjang pendidikan. Pendidik dapat membuat soal dengan mudah sesuai materi ajar berdasarkan KD dan Indikator. Aplikasi ini dapat digunakan jarak jauh oleh pendidik dan peserta didik.

\section{Daftar Rujukan}

Adhi, S. B. (2018). Rancang Bangun Program Aplikasi Quiz Bahasa Inggris Menggunakan Microsoft Visual Basic 6.0. Jurnal Akrab Juara, 3(4), 292-302. http://akrabjuara.com/index.php/akrabjuara/article/view/416.

Aka, K. A. (2017). Pemanfaatan Teknologi Informasi dan Komunikasi (TIK) sebagai Wujud Inovasi Sumber Belajar di Sekolah Dasar. Jurnal Pendidikan Dan Pembelajaran Sekolah Dasar, 1(2), 28-37. http://journal.umsurabaya.ac.id/index.php/pgsd/article/view/1041/724.

Anugrahana, A. (2020). Hambatan, Solusi dan Harapan : Pembelajaran Daring Selama Masa 
Pandemi Covid-19 Oleh Guru Sekolah Dasar. Jurnal Pendidikan Dan Kebudayaan, 10(3), 282-289. https://doi.org/10.24246/j.js.2020.v10.i3.p282-289.

Aprianto, N. E. K. (2021). The Role of Information and Communication Technology in Business. International Journal Administration Business \& Organization, 2(1), 8-15. https://ijabo.a3i.or.id/index.php/ijabo/article/view/152.

Astuti, I. A. D., Sumarni, R. A., \& Saraswati, D. L. (2017). Pengembangan Media Pembelajaran Mobile Learning Berbasis Android. JRPK: Jurnal Riset Pendidikan Kimia, 3(1), 57-62. https://doi.org/10.21009/jrpk.072.10.

Cucus, A., \& Aprilinda, Y. (2016). Pengembangan E-Learning Berbasis Multimedia untuk Efektivitas Pembelajaran Jarak Jauh. Explore: Jurnal Sistem Informasi Dan Telematika, 7(1). https://doi.org/10.36448/jsit.v7i1.765.

Damayanti, N. A., \& Dewi, R. M. (2021). Pengembangan Aplikasi Kahoot Sebagai Media Evaluasi Hasil Belajar Siswa. Jurnal Ilmu Pendidikan, 3(4), 1647-1659. https://doi.org/10.31004/edukatif.v3i4.656.

Fazriyah, N., Cartono, C., \& Awangga, R. M. (2020). Pelatihan Aplikasi Pembelajaran Quizizz di Sekolah Dasar Kota Bandung. Jurnal Penelitian Dan Pengabdian Kepada Masyarakat, 8(2), 199-204. https://doi.org/10.29313/ethos.v8i2.5429.

Hanik, E. U. (2020). Self directed learning berbasis literasi digital pada masa pandemi covid19 di Madrasah Ibtidaiyah. ELEMENTARY: Islamic Teacher Journal, 8(1), 183. https://doi.org/10.21043/elementary.v8i1.7417.

Huda, M. (2018). Blanded Learning: Improvisasi dalam Pembelajaran Menulis Pengalaman. Kajian Kebahasaan, Kesusastraan, Dan Budaya, 8(2), 117-130. https://doi.org/10.26714/lensa.8.2.2018.117-130.

Ichsan, I. Z., Rahmayanti, H., Purwanto, A., Sigit, D. V., Irwandani, I., Ali, A., Susilo, S., Kurniawan, E., \& Rahman, M. (2020). COVID-19 Outbreak on Environment: Profile of Islamic University Students in HOTS-AEP-COVID-19 and PEB-COVID-19. Tadris: Jurnal Keguruan Dan Ilmu Tarbiyah, 5(1), 167-178. https://doi.org/10.24042/tadris.v5i1.6283.

Kurniawan, B., Purnomo, A., \& . I. (2020). Penggunaan Aplikasi Google Classroom Sebagai Upaya Peningkatan Pembelajaran Online Bagi Guru Matapelajaran IPS. International Journal of Community Service, 4(1), 1-9. https://doi.org/10.23887/ijcsl.v4i1.22236.

Kuswanto, J., Walusfa, Y., Artikel, S., Korespondensi, A., Ratu Penghulu No, J., Sari, K., Baru, T., Raja Tim, B., Ogan Komering Ulu, K., \& Selatan, S. (2017). Pengembangan Multimedia Pembelajaran pada Mata Pelajaran Teknologi Informasi dan Komunikasi Kelas VIII. Innovative Journal of Curriculum and Educational Technology IJCET, 6(2), 58-64.

Nurhayati, S., \& Muharamsah, L. (2020). Aplikasi Pembelajaran Interaktif Ilmu Pengetahuan Sosial Pada Smp Negeri 1 Carita. JOINS (Journal of Information System), 5(2), 200207. https://doi.org/10.33633/joins.v5i2.3491.

Pakpahan, R., \& Fitriani, Y. (2020). Analisa Pemafaatan Teknologi Informasi Dalam Pemeblajaran Jarak Jauh Di Tengah Pandemi Virus Corona Covid-19. JISAMAR (Journal of Information System, Applied, Management, Accounting and Researh), 4(2), 30-36. http://journal.stmikjayakarta.ac.id/index.php/jisamar/article/view/181.

Pudyastuti, A. T., \& Budiningsih, C. A. (2021). Efektivitas Pembelajaran E-Learning pada Guru PAUD Selama Pandemic Covid-19. Jurnal Obsesi : Jurnal Pendidikan Anak Usia Dini, 5(1), 1667-1675. https://doi.org/10.31004/obsesi.v5i2.873.

Safitri, E. R., \& Nurkamilah, S. (2020). Pengembangan Bahan Ajar Digital Berbasis Android untuk Peserta Didik Berkebutuhan Khusus. Journal of Education and Instruction, 3(2), 296-304. https://doi.org/10.31539/joeai.v3i2.1612.

Sayyidati, R., \& Effendy, I. (2018). Aplikasi Latihan Soal PKN (Pancasila dan 
Kewarganegaraan) Studi Kasus: SMA PGRI Pelaihari. Jurnal Sains Dan Informatika, 4(1), 45-50. https://doi.org/10.34128/jsi.v4i1.129.

Setiawan, A. R. (2020). Pembelajaran Tematik Berorientasi Literasi Saintifik. Jurnal Basicedu, 3(2), 524-532. https://doi.org/https://doi.org/10.31004/basicedu.v4i1.298.

Shetu, S. F., Rahman, M. M., Ahmed, A., Mahin, M. F., Akib, M. A. U., \& Saifuzzaman, M. (2021). Impactful e-learning framework: A new hybrid form of education. Current Research in Behavioral Sciences, 2(April), 100038. https://doi.org/10.1016/j.crbeha.2021.100038.

Sjukur, S. B. (2012). The Effects of Blended learning On The Learning Motivation and Achievement Students level SMK. Jurnal Pendidikan Vokasi, 2(3), 368-278. https://doi.org/https://doi.org/10.21831/jpv.v2i3.1043.

Sofralda, Suci \& Atika Latifa, A. M. P. (2019). Analisis Penerapan Metode Pembelajaran Jarak Jauh Menggunakan Media Daring Di SMPIT Al-Islah Cibinong. Jurnal Ilmiah Islam, 2(1), 11-17. http//jurnal.iuqibogor.ac.id.

Suprihatin, S. (2015). Upaya Guru Dalam Meningakatkan Motivasi Belajar Siswa. PROMOSI (Jurnal Pendidikan Ekonomi), 3(1), 73-82. https://doi.org/10.24127/ja.v3i1.144.

Sutrisno, V. L. P., \& Siswanto, B. T. (2016). Faktor-Faktor Yang Mempengaruhi Hasil Belajar Siswa Pada Pembelajaran Praktik Kelistrikan Otomotif Smk Di Kota $\begin{array}{lllll}\text { Yogyakarta. Jurnal Pendidikan } & \text { Vokasi, } & 6(1), & \end{array}$ https://doi.org/10.21831/jpv.v6i1.8118.

Wan Normeza Wan Zakaria, Abas, H., Masrom, M., Mohdali, R., \& Mohamed, N. N. N. (2019). Development of Self-learning Economics App for Secondary School Students in Malaysia Based on Information Processing Model. TEM JOURNAl, 8(3), 908 914. https://doi.org/10.18421/TEM83-31.

Wardani, W. (2021). Pengaruh Lingkungan Belajar, Fasilitas, dan Metode Mengajar Guru melalui Motivasi terhadap Hasil Belajar. Journal of Education, Humaniora and Social Sciences (JEHSS), 3(3), 1307-1315. https://doi.org/10.34007/jehss.v3i3.553.

Yana, A. U., Antasari, L., \& Kurniawan, B. R. (2019). Analisis pemahaman konsep gelombang mekanik melalui aplikasi online quizizz. , 7(2), . Jurnal Pendidikan Sains Indonesia (Indonesian Journal of Science Education), 7(2), 143-152. https://doi.org/10.24815/jpsi.v7i2.14284.

Yasa, A. D., Suastika, K. K., \& Zubaidah, R. S. A. N. (2020). Pengembangan E-Evaluation Berbasis Aplikasi Hot Potatoes Untuk Siswa Kelas V Sekolah Dasar. Jurnal Ilmiah Sekolah Dasar, 4(1), 26-32. https://doi.org/10.23887/jisd.v4i1.23987. 